\title{
Crustal structure of western Hispaniola (Haiti) from a teleseismic receiver function study
}

\author{
J. Corbeau ${ }^{\mathrm{a}, \mathrm{b}, *}$, F. Rolandone ${ }^{\mathrm{a}}$, S. Leroy ${ }^{\mathrm{a}}$, K. Guerrier ${ }^{\mathrm{c}}$, D. Keir ${ }^{\mathrm{d}, \mathrm{e}}$, G. Stuart $^{\mathrm{f}}$, V. Clouard ${ }^{\mathrm{b}}$, R. Gallacher ${ }^{\mathrm{d}}$, S. Ulysse $^{\mathrm{c}}$, \\ D. Boisson ${ }^{\text {c }}$, R. Bien-aimé Momplaisir ${ }^{\text {c }}$, F. Saint Preux ${ }^{\text {g }}$, C. Prépetit ${ }^{\mathrm{g}}$, J.-M. Saurel ${ }^{\mathrm{b}}$, \\ B. Mercier de Lépinay ${ }^{\mathrm{h}}$, B. Meyer ${ }^{\mathrm{a}}$
}

a Sorbonne Universités, UPMC Univ Paris 06, CNRS, Institut des Sciences de la Terre de Paris (ISTeP), 4 place Jussieu, 75005 Paris, France

b Observatoire Volcanologique et Sismologique de Martinique (OVSM), Institut de Physique du Globe de Paris (IPGP), UMR 7154, CNRS Sorbonne Paris Cité, Paris, France

' URGeo, Faculté des Sciences, Université d'Etat d'Haiti, Port-au-Prince, Haiti

d Ocean and Earth Science, National Oceanography Center Southampton, University of Southampton, Southampton SO14 3ZH, UK

e Dipartimento di Scienze della Terra, Universita degli Studi di Firenze, Florence 50121, Italy

${ }^{\mathrm{f}}$ Institute of Geophysics and Tectonics, School of Earth and Environment, University of Leeds, Leeds LS2 9JT, UK

${ }^{g}$ Bureau des Mines et de l'Energie, Unité Technique de Sismologie, Port-au-Prince, Haiti

${ }^{\text {h }}$ Université Côte d'Azur, CNRS/IRD/OCA, Géoazur, Valbonne, France

\section{A R T I C L E I N F O}

\section{Article history:}

Received 12 December 2016

Received in revised form 25 April 2017

Accepted 26 April 2017

Available online 27 April 2017

\section{Keywords:}

Receivers function

Haiti

Crustal structure

\begin{abstract}
A B S T R A C T
Haiti, located at the northern Caribbean plate boundary, records a geological history of terrane accretion from Cretaceous island arc formations to the Eocene to Recent oblique collision with the Bahamas platform. Little is presently known about the underlying crustal structure of the island. We analyze P-waveforms arriving at 27 temporary broadband seismic stations deployed over a distance of $200 \mathrm{~km}$ across the major terrane boundaries in Haiti to determine the crustal structure of western Hispaniola. We compute teleseismic receiver functions using the Extended-Time Multi-Taper method and determine crustal thickness and bulk composition $\left(\mathrm{V}_{\mathrm{p}} / \mathrm{V}_{\mathrm{s}}\right)$ using the H-к stacking method. Three distinctive and fault-bounded crustal domains, defined by their characteristic Moho depth distributions and bulk crustal $V_{p} / V_{s}$, are imaged across Haiti. We relate these domains to three crustal terranes that have been accreted along the plate boundary during the northeastwards displacement of the Caribbean plate and are presently being deformed in a localized fold and thrust belt. In the northern domain, made up of volcanic arc facies, the crust has a thickness of $\sim 23 \mathrm{~km}$ and $\mathrm{Vp} / \mathrm{Vs}$ of $1.75 \pm 0.1$ typical of average continental crust. The crust in the southern domain is part of the Caribbean Large Igneous Province (Caribbean LIP), and is $\sim 22 \mathrm{~km}$ thick with $\mathrm{Vp} / \mathrm{Vs}$ of $1.80 \pm 0.03$ consistent with plume-related rocks of late Cretaceous age. Significantly thicker, the crust in central Haiti has values of Moho depths averaging $41 \mathrm{~km}$ and with $\mathrm{Vp} / \mathrm{Vs}$ of $1.80 \pm$ 0.05 . We propose that the central domain is likely constructed of an island arc upper crust with fragments of dense material originating from mafic lavas or LIP material. We produce a crustal profile along a N-S transect across Haiti accounting for the surface geology, shallow structural history, and new seismological constraints provided by variations of crustal thickness and bulk composition.
\end{abstract}

(c) 2017 Elsevier B.V. All rights reserved.

\section{Introduction}

\subsection{Overview}

One of the keys to understanding the transpressive northern Caribbean plate boundary and its geodynamic evolution is constraining crustal thickness and composition. Several geological field studies have led to a description of the shallow structure and stratigraphy of

* Corresponding author at: Sorbonne Universités, UPMC Univ Paris 06, CNRS, Institut des Sciences de la Terre de Paris (ISTeP), 4 place Jussieu, 75005 Paris, France.

E-mail address: corbeau@ipgp.fr (J. Corbeau). the island of Hispaniola (e.g., Mann et al., 1995; Pubellier et al., 2000). The Mw 7.0 2010 Haiti earthquake prompted several geological and geophysical studies to constrain the fault geometry and the crustal structure in the area of the mainshock (e.g., Douilly et al., 2013). However, our knowledge of the mid- and lower-crustal tectonics remains very limited in the absence of whole crustal geophysical studies in Haiti. In Dominican Republic, the eastern part of Hispaniola Island, interpretation of crustal thickness from gravity data shows thick crust below the southern flank of the Dominican Central Cordillera (Bowin, 1976). From April 2013 for nearly 14 months, a temporary seismic network consisting of 27 stations was deployed in Haiti (Trans-Haiti project) to determine its crustal thickness and bulk composition using teleseismic 
P-wave data. In addition, we analyze seismograms from 3 permanent stations of the Canadian National network (2010-2015) operated by the Bureau des Mines et de l'Energie and UTS. This paper is the first one about works on temporary deployment of seismometers cross-cutting the whole of the island.

The purpose of the present study is to determine crustal structure across Haiti from receiver function (RF) analysis below Haiti so as to better constrain plate scale tectonic evolution of the region responsible for the development of the current fold-thrust belt (Mann et al., 1995; Pubellier et al., 2000; Hernaiz Huerta et al., 2007). The receiver function analysis technique is an appropriate approach to image major discontinuities within the crust and upper mantle from incoming teleseismic Pwaveforms (e.g. Ammon, 1991).

\subsection{Geological and tectonic setting of Haiti}

Haiti, the western part of the Hispaniola island, is located on the Northern Caribbean plate boundary, which separates the Caribbean plate from the North American plate (Fig. 1). Currently, the Caribbean plate moves in a east-northeast direction at about $20 \mathrm{~mm} / \mathrm{yr}$ relative to the North American plate (Symithe et al., 2015). As the plate boundary is oriented $\mathrm{E}-\mathrm{W}$ and the displacement vector of the Caribbean plate is about $\mathrm{N}^{\circ} 0^{\circ}$, the area undergoes oblique collision and transpression at a large restraining bend in the strike-slip plate boundary. The deformation of the Northern Caribbean plate boundary in Haiti is partitioned and two major E-W left-lateral strike-slip faults, the SeptentrionalOriente Fault Zone (SOFZ) in the North and the Enriquillo-Plantain-Garden Fault Zone (EPGFZ) in the south with both faults accommodating the strike-slip component of the displacement (Fig. 1). GPS geodesy shows that compression is mainly accommodated by Miocene to recent folding and thrusting in the North-Haitian thrust fault and the Massif de la Selle in southern Haiti (Symithe and Calais, 2016). The Trans-Haitian fold-and-thrust belt in central Haiti (Fig. 1) was active until the late Neogene (Mann et al., 1995) but does not appear to accommodate significant shortening today.

The geological and geodynamical history of Haiti is complex, however, two distinct domains have been identified. Haiti is part of the Cretaceous volcanic island arc constituted at the boundary of the Pacific realm (Pindell et al., 2006) called the Greater Antilles arc. The Greater
Antilles volcanic arc was initiated by an eastward dipping subduction in Central America (Pindell et al., 2012; Van der Lelij, 2013; Hastie et al., 2013). The Greater Antilles arc now consists of a part of Cuba, Hispaniola and Puerto Rico islands (Mann et al., 1995). This island arc constitutes two thirds of Hispaniola Island, and is mainly made up of arc magmatic facies (Boisson, 1987; Escuder Viruete et al., 2006). The southern part of Haiti has been interpreted to be part of the Caribbean Large Igneous Province (LIP), formed during the Cretaceous on the Pacific Farallon plate, over the Galapagos hotspot (Duncan and Hargraves, 1984). The LIP outcrops as a tholeitic substratum associated with Upper Cretaceous sediments in the Southern Peninsula of Haiti (Calmus, 1983), and has been imaged south and west of Haiti with refraction and reflection data (Leroy et al., 2000; Mauffret et al., 2001; Corbeau et al., 2016a). The volcanic island arc and the LIP subsequently moved north- and eastwards from their Pacific position between the North and South American plates, thus partitioning the current Caribbean plate (Pindell et al., 2012). The Greater Antilles arc became an inactive intra-oceanic arc at the end of the Upper Cretaceous when it collided with the Bahamas carbonate platform (Leroy et al., 2000; Cruz-Orosa et al., 2012; Iturralde-Vinent, 2006). Between the island arc and the LIP lies the Quaternary Cul-de-Sac sedimentary basin (Fig. 1), which is bounded to the North by the thrusts of the Trans-Haitian belt, also called Haiti fold-and-thrust belt. This belt is formed of NWSE thrusts having propagated towards the SW since the Lower Miocene (Pubellier et al., 2000).

\subsection{Previous geophysical work}

Previous geophysical studies have placed crude constraints on crustal structure in the south and in the vicinity of Haiti that help place our results in context and aid interpretation.

A compilation of seismic refraction data acquired in the Caribbean plate shows that the thickness of the crust is not uniform (Diebold et al., 1981; Mauffret and Leroy, 1997; Mauffret et al., 2001). The Caribbean oceanic crust is 5-km thick in Haitian sub-basin, Colombia and Venezuela basins (Fig. 1). In the middle of the Caribbean plate, the original oceanic crust is underplated by ultra-mafic material (Leroy et al., 2000), forming a LIP of $\sim 10$ to $15 \mathrm{~km}$ in thickness. The Beata Ridge (Fig. 1), 20-30 km thick, is composed of oceanic crust underplated by

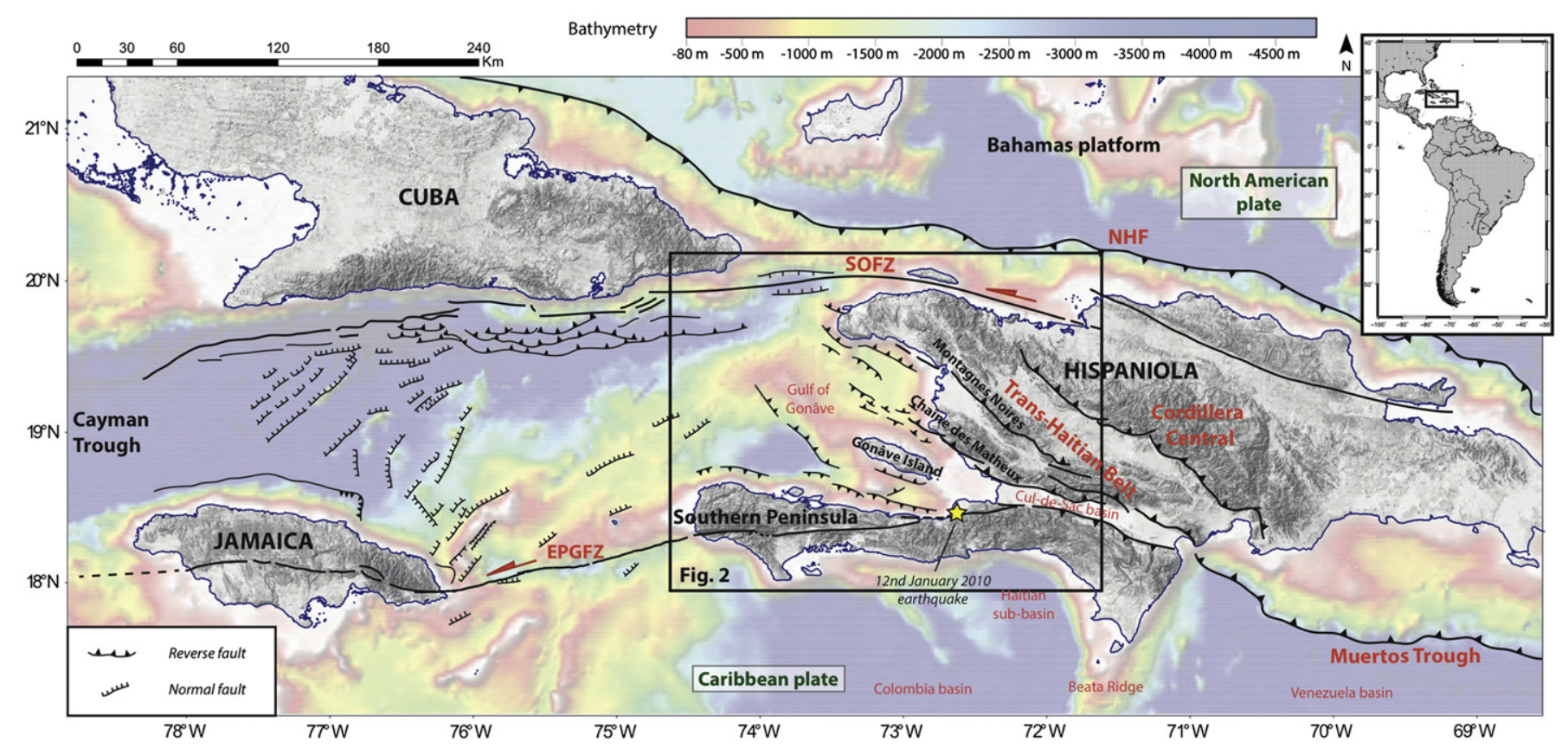

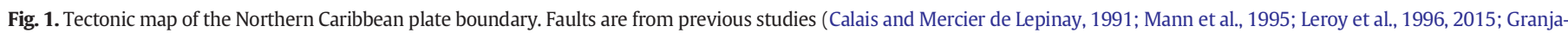
Bruña et al., 2014). NHF: North-Hispaniola Fault; SOFZ: Septentrional-Oriente Fault Zone; EPGFZ: Enriquillo-Plantain-Garden Fault Zone. 
an $15-20 \mathrm{~km}$ higher velocity ( 6 to $8 \mathrm{~km} / \mathrm{s}$ ) ultra-mafic magmatic material and covered by a thin volcanic layer of $\sim 2 \mathrm{~km}$ (basaltic with a Pwave velocity of 4.5 to $6 \mathrm{~km} / \mathrm{s}$ ). Submersible sampling along the Beata Ridge to the South of Haiti (Mauffret et al., 2001) confirmed the deep origin of the underplated materials that are ultra-mafic rocks such as picrites or komatiites (Revillon et al., 2000).

In addition, Douilly et al. (2013) provide a velocity model for the crust in the southern part of Haiti, and show that the mean $\mathrm{Vp} / \mathrm{Vs}$ in this area is 1.80 , which is typical for oceanic crust mafic rocks (Christensen, 1996). Velocity model and receiver functions studies made by Moreno et al. (2002) and González et al. (2012) show that the depth of the Moho is approximately $20 \mathrm{~km}$ in the south of Cuba. In eastern Hispaniola, a seismic refraction study shows that the Moho is at approximately $24 \mathrm{~km}$ depth, and reaches roughly $30 \mathrm{~km}$ deep in the central part of Hispaniola (Nuñez et al., 2015). The S- and Lg-wave study of McNamara et al. (2012) implies that the Moho in the southwestern part of Hispaniola is $20.6 \mathrm{~km}$ depth.

\section{Data and method}

\subsection{Data}

We use data from the 27 broadband stations of the temporary TransHaiti network deployment (April 2013-June 2014), spanning Haiti from North to South (Fig. 2). This unique data set used SEIS-UK and iSTeP UPMC instruments that included 15 CMG-40TD and 12 CMG-6TD seismometers (30s natural period, 100 sps sampling rate). Additionally, we use data from 3 broadband permanent stations of the Canadian National Seismic network installed in Haiti after the $2010 \mathrm{Mw} 7.0$ earthquake and co-operated by the Bureau des Mines et de l'Energie - UTS (Fig. 2).

To construct receiver functions we use seismograms from teleseismic earthquakes of magnitudes $\mathrm{Mw}>5.0$, with epicentral distances between $30^{\circ}$ and $90^{\circ}$. The initial data set includes a total of 580 events recorded by the Trans-Haiti stations between April 2013 and June 2014, and 2473 events for the Canadian stations between February 2010 and August 2015. The data are generally noisy, due to cultural noise sources, and a second order Butterworth filter with corner frequencies of 0.03 and $2 \mathrm{~Hz}$ is applied to the data prior to analysis. A visual quality control is subsequently performed on all the data such that only seismograms

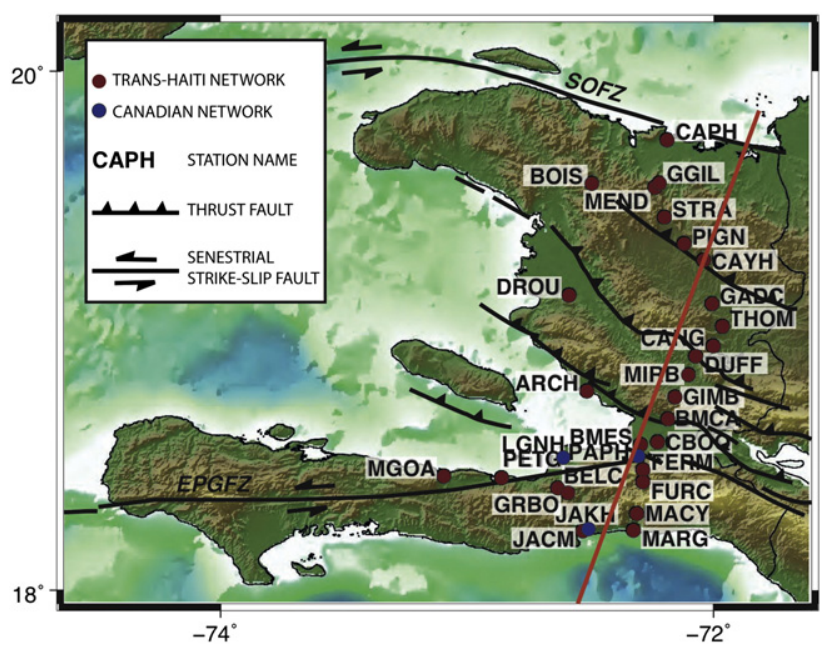

Fig. 2. Locations of the seismic stations used in this receiver function study in Haiti, superimposed on the topographic map and with the major tectonic features. Red circles are the stations of the Trans-Haiti network and blue circles are the 3 permanent stations of the Canadian National Network. Faults are from Pubellier et al. (2000). SOFZ: Septentrional-Oriente Fault Zone; EPGFZ: Enriquillo-Plantain-Garden Fault Zone. The red line indicates the localization of the transect proposed Fig. 10.

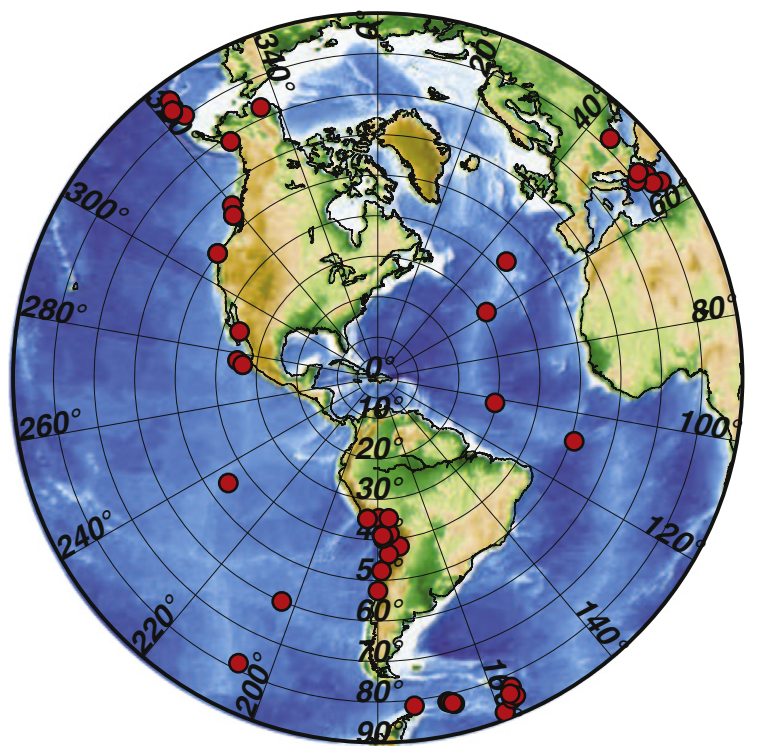

Fig. 3. Global distribution of the earthquakes used when computing receiver functions. They are plotted with an azimuthal equidistant map projection around our network.

that have clear direct-P arrivals are used to produce receiver functions. This results in a reduced data set of 149 event records, with a range of between 2 and 13 per station. A map showing the epicentral distribution of the analyzed earthquakes is given in Fig. 3. Note that the majority of the events arrive from the south of the seismic network.

\subsection{Receiver function technique}

To image the crustal structure beneath Haiti we use the receiver function (RF) method (e.g. Ammon, 1991), which is a deconvolution technique for isolating the P-to-S converted phases (Ps) and associated reverberations (PpPs and PsPs + PpSs) of an incoming P-waveform beneath a seismic station. The incident P-wave on the vertical component is deconvolved from the radial and tangential components to remove source complexity and leave a series of pulses that represent the P-to$S$ phase conversions (the so-called receiver function).

Several deconvolution methods have been developed with different noise stabilization processes: deconvolution in the frequency domain (Langston, 1979; Owens et al., 1983; Ammon, 1991); deconvolution in the time domain by least squares estimation (Abers et al., 1995); iterative

Table 1

Moho depth $(\mathrm{H})$ and $\mathrm{Vp} / \mathrm{Vs}$ ratio (К) estimated by the H-к stacking method.

\begin{tabular}{llllll}
\hline Stations & $\mathrm{N}$ & $\mathrm{H}(\mathrm{km})$ & $\delta_{\mathrm{H}}(\mathrm{km})$ & $\mathrm{K}$ & $\delta \mathrm{K}$ \\
\hline BMCA (line A) & 13 & 44.3 & 0.1 & 1.98 & 0.01 \\
BOIS (line D) & 2 & 41.5 & 0.1 & 1.75 & 0.01 \\
CANG (line A) & 4 & 41.5 & 0.4 & 1.99 & 0.01 \\
CAYH (line B) & 5 & 22.1 & 0.4 & 1.64 & 0.02 \\
CBOQ (line A) & 7 & 39.5 & 0.7 & 1.82 & 0.02 \\
DROU (line D) & 7 & 47.2 & 0.4 & 1.85 & 0.02 \\
DUFF (line A) & 3 & 45.2 & 0.4 & 1.73 & 0.01 \\
FERM (line A) & 2 & 20.5 & 0.4 & 1.79 & 0.03 \\
FURC (line A) & 3 & 26.6 & 0.3 & 1.83 & 0.02 \\
GGIL (line C) & 3 & 20.1 & 0.7 & 1.81 & 0.04 \\
GRBO (line E) & 3 & 29.8 & 0.3 & 1.83 & 0.02 \\
JACM (line D) & 3 & 20.9 & 0.4 & 1.80 & 0.03 \\
LGNH (line D) & 8 & 34.6 & 0.4 & 1.96 & 0.02 \\
MEND (line C) & 6 & 22.5 & 0.4 & 1.94 & 0.02 \\
MGOA (line E) & 10 & 16.1 & 0.5 & 1.74 & 0.04 \\
PETG (line E) & 3 & 19.7 & 0.4 & 1.83 & 0.03 \\
PIGN (line B) & 4 & 22.1 & 0.5 & 1.86 & 0.04 \\
STRA (line B) & 4 & 28.2 & 0.4 & 1.67 & 0.03 \\
THOM (line A) & 5 & 37.9 & 0.5 & 1.87 & 0.02 \\
\hline
\end{tabular}


deconvolution in the time domain (Gurrola et al., 1995; Ligorría and Ammon, 1999) and multi-taper frequency domain cross-correlation (MTRF) (Park and Levin, 2000; Helffrich, 2006). The advantage of the last method is that it works on the correlated signal and mitigates against noise on the RFs. It has been recommended in the case of oceanic island studies, such as the Cape Verde islands (Helffrich et al., 2010), the

i. $\mathrm{Vp} / \mathrm{Vs}=1.86+/-0.04, \mathrm{H}=22.1+/-0.515 \mathrm{~km}$
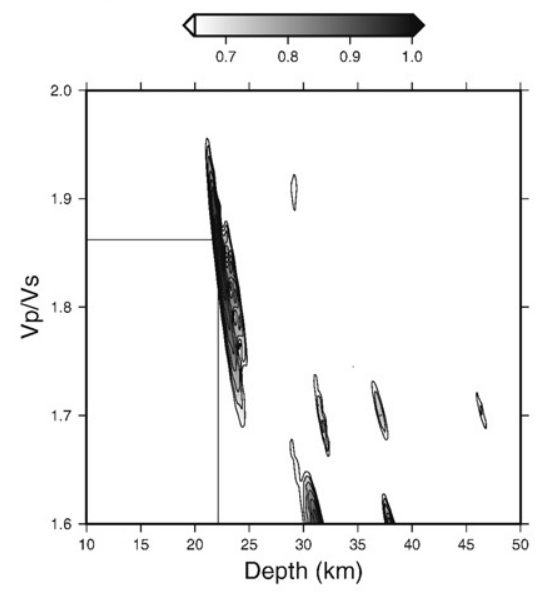

ii.

LGNH, $\mathrm{Vp}=6.6 \mathrm{~km} / \mathrm{s}, \mathrm{N}=8$ $\mathrm{Vp} / \mathrm{Vs}=1.96+/-0.021, \mathrm{H}=34.6+/-0.435 \mathrm{~km}$

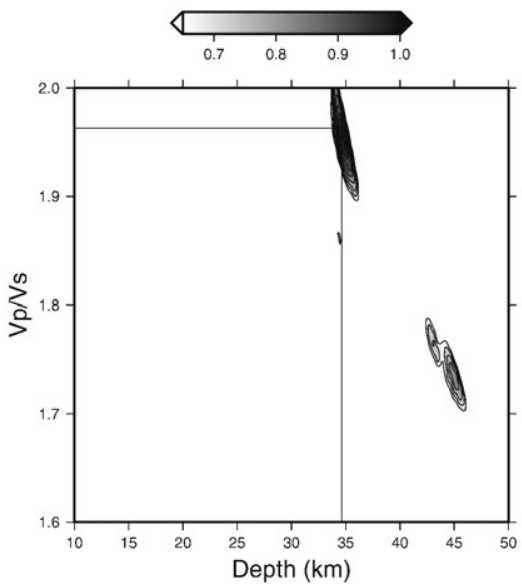

iii.

MGOA, $\mathrm{Vp}=6.6 \mathrm{~km} / \mathrm{s}, \mathrm{N}=10$ $\mathrm{Vp} / \mathrm{Vs}=1.74+/-0.044, \mathrm{H}=16.1+/-0.485 \mathrm{~km}$

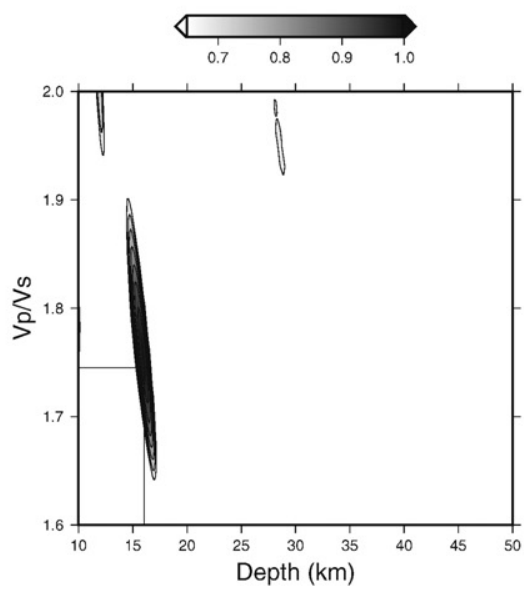

PIGN northern domain

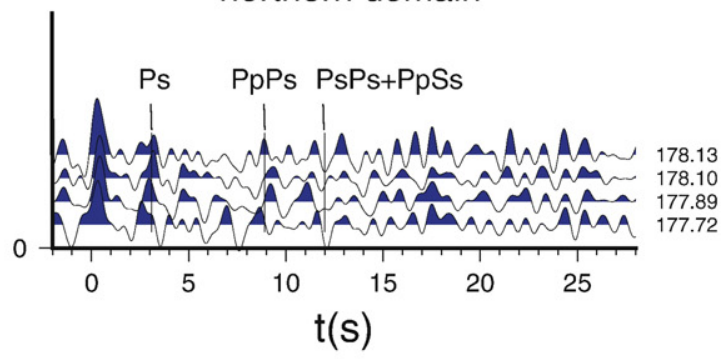

\section{LGNH central domain}
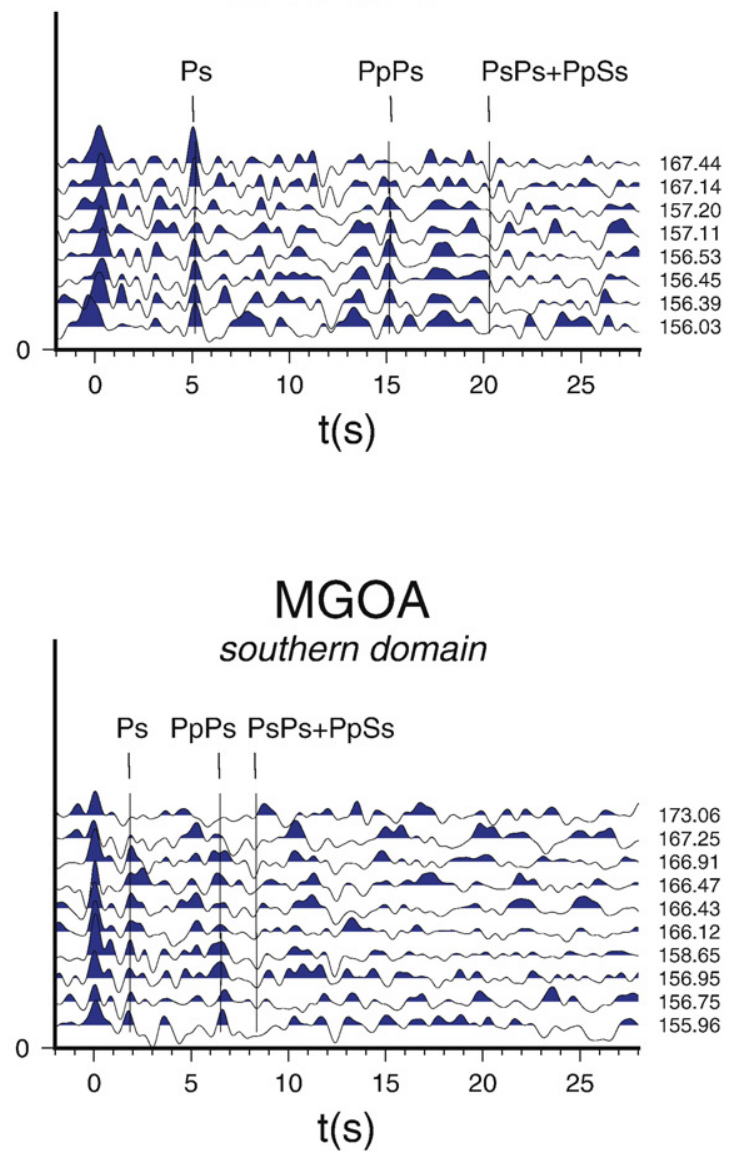

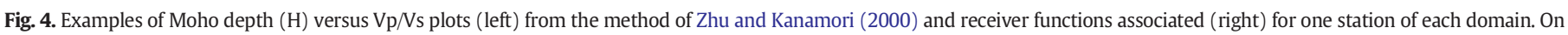

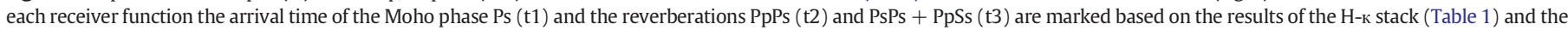

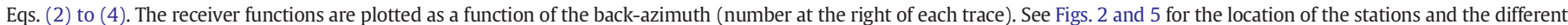
domains. 
Seychelles islands (Hammond et al., 2013), and the Canary islands (Lodge et al., 2012; Martinez-Arevalo et al., 2013), and in our case we choose it for its capacity to remove anthropic noise.

To estimate the Moho depth below the island of Haiti, we use the Extended-Time Multitaper Frequency domain Cross-Correlation ReceiverFunction (ETMTRF) technique of Helffrich (2006), which is based on the MTRF method of Park and Levin (2000). The ETMTRF method uses a series of short and overlapping multiple tapers which window the time series across its full length, and sum the individual Fourier transformed signals to produce a RF estimate.

\subsection{Moho depth and Vp/Vs estimation}

We use a receiver function stacking technique (Н-к stacking) developed by Zhu and Kanamori (2000) to estimate the Moho depth $(\mathrm{H})$ and the bulk crust ratio $V p / V_{s}(\kappa)$. This method uses the following Eqs. (1), (2), (3), and (4) for stacking the RFs, and gives the results on a 10,000 point grid which shows the plausible range of values for $\mathrm{H}$ on increments of $0.4 \mathrm{~km}$ between 10 and $50 \mathrm{~km}$ and $\kappa$ on increments of 0.004 between 1.6 and 2.0 (Christensen, 1996):

$s(H, \kappa)=\sum_{j=1}^{N} w_{1} r_{j}\left(t_{1}\right)+w_{2} r_{j}\left(t_{2}\right)-w_{3} r_{j}\left(t_{3}\right)$

$t_{1}=H\left[\sqrt{\frac{1}{V_{s}^{2}}-p^{2}}-\sqrt{\frac{1}{V_{p}^{2}}-p^{2}}\right]$,

$t_{1}=H\left[\sqrt{\frac{1}{V_{s}^{2}}-p^{2}}+\sqrt{\frac{1}{V_{p}^{2}}-p^{2}}\right]$,

$t_{3}=2 H \sqrt{\frac{1}{V_{p}^{2}}-p^{2}}$

where $w_{1}, w_{2}, w_{3}$ are weights, $r_{j}\left(t_{i}\right)$ are the amplitudes at the arrival times for each of the raypaths evaluated, $N$ is the number of receiver functions, and $p$ is the ray parameter determined from the IASPEI travel time tables (Kennet, 1991). The weights were chosen as $w_{1}=0.5, w_{2}=$ 0.3 and $w_{3}=0.2$ as suggested by Zhu and Kanamori (2000). The errors in the results were calculated by taking the maximum axes of the $95 \%$ confidence interval of the grid plotted using the Zhu and Kanamori (2000) stacking method. The H-к stack was performed assuming a mean crustal P-wave velocity $\left(V_{p}\right)$ of $6.6 \mathrm{~km} / \mathrm{s}$. This mean crustal Pwave velocity comes from a study of the Pg seismic phase over Hispaniola (McNamara et al., 2012). Crustal thickness, H, and average Vp/Vs determination is not very sensitive to variations in the average $\mathrm{Vp}$, as pointed out by Zhu and Kanamori (2000), and testing Vp within the range $6.4-6.7 \mathrm{~km} / \mathrm{s}$ on increments of $0.1 \mathrm{~km} / \mathrm{s}$ provides very similar results of $\mathrm{H}$ and $\mathrm{Vp} / \mathrm{Vs}$ ratio.

Our final analysis uses the RFs computed from 149 earthquakes, from which one or more reverberant Moho phases (PpPs or PpSs + PsPs) were clearly identifiable.

\section{Results}

Of the 30 stations, 27 yielded receiver functions with coherent P-to-S arrivals. Of these, 19 displayed PpPs and PpSs + PsPs arrivals as well as Ps, enabling $\mathrm{H}-\mathrm{\kappa}$ analysis (Table 1). Examples of stacked receiver functions and H-K plots for stations PIGN, LGNH, and MGOA are shown in Fig. 4. For the 8 stations at which no clear reverberant phases were found automatically by the program, RFs were combined to form single station stacks and enhance the signal of the reverberations. At these stations, a clear Ps arrival is identifiable and can be picked manually, but the H-к stacking technique cannot be performed. We can still however estimate the Moho depth using Eq. (2) and by assuming a Vp/Vs ratio after several tests. Final Vp/Vs ratios chosen are the values providing arrival times for the PpPs and PpSS + PsPs reverberations that match the signal stacks, and which are coherent with the $\mathrm{Vp} / \mathrm{Vs}$ of the surrounding stations (Table 2).

The results show large but systematic variations in Moho depth and $V p / V_{s}$ ratio throughout Haiti (Figs. 5 and 6). The Moho depths can be split into three main groups shown in Fig. 5 and based on location and values (in latitudinal order GGIL, MEND, STRA, PIGN and CAYH in the northern part of Haiti; BOIS, DROU, GADC, THOM, CANG, DUFF, MIRB, ARCH, GIMB, BMCA, CBOQ, BMES, PAPH and LGNH in the central part, and MGOA, PETG, GRBO, JAKH, JACM, FERM, FURC, and MARG in the southern part of Haiti).

\subsection{Moho depths in Haiti}

Results from the Н-к stacking method in the northern domain of Haiti are well resolved, with the stations STRA, PIGN and CAYH particularly well constrained. Results are also consistent across this domain giving Moho depths of between $20.1 \mathrm{~km}$ and $28.2 \mathrm{~km}$ (Table 1, Fig. 5).

Results in the southern part of Haiti are also well resolved, with the stations MGOA, JACM and PETG particularly well constrained. Results across the domain give Moho depths ranging between $16.1 \mathrm{~km}$ and $29.8 \mathrm{~km}$, increasing in the center of the area at the stations GRBO, MARG, FURC (Table 1, Fig. 5). The stations MARG and JAKH have clearly identifiable Ps arrivals, but due to the lack of observable multiples the $\mathrm{H}$ к stacking technique cannot be performed. However, we can still estimate the depth of the Moho by using Eq. (2) (Table 2, Fig. 5).

Our results show that the central part of Haiti exhibits greater Moho depths than in the northern and southern parts, with a Moho discontinuity always deeper than $30 \mathrm{~km}$. The RFs of the stations located in this part of Haiti are more complicated due to intracrustal reverberations, probably due to sediments layers. However, consistent values are found for the stations THOM, CANG, DUFF, BMCA, CBOQ, DROU, LGNH and BOIS with Moho depths ranging between $34.6 \mathrm{~km}$ and $45.2 \mathrm{~km}$ (Table 1, Fig. 5). We estimate the Moho depth for the stations GADC, MIRB, GIMB, BMES, $\mathrm{ARCH}$, and PAPH by assuming a $\mathrm{Vp} / \mathrm{Vs}$ ratio from the closest stations (Table 2, Fig. 5). Transect A in Fig. 7 shows the abrupt change in Moho depth of $\sim 10 \mathrm{~km}$ between the southern part and the central part of Haiti.

\section{2. $V p / V s$ ratio}

The average crustal Vp/Vs ratio is sensitive to the bulk composition of the crust (Zandt and Ammon, 1995; Chevrot and Van der Hilst, 2000; Stuart et al., 2006). Mineralogy is an important factor influencing Vp/Vs ratio (Christensen, 1996): For felsic quartz-rich rocks, such as granite, $\mathrm{Vp} / \mathrm{Vs}$ ratio is $\sim 1.71$; for intermediate rocks, such as diorite, $\mathrm{Vp} / \mathrm{Vs}$ ratio is typically $\sim 1.78$; and for mafic rocks, such as gabbro $\mathrm{Vp} / \mathrm{Vs}$ ratio is $\sim 1.87$. Higher values of $\mathrm{Vp} / \mathrm{Vs}$ ratio are associated with the presence of partial melting or fluids (Watanabe, 1993; Thompson et al., 2010).

The $\mathrm{Vp} /$ Vs ratio over Haiti ranges from 1.64 to 1.99 (Fig. 6) suggesting a wide range of mineral composition lateral variation. In particular, the stations MEND, CANG, BMCA and LGNH show particularly high Vp/Vs ratios of 1.94, 1.99, 1.98 and 1.96 respectively (Fig. 6). We observe that these stations are located on or near major tectonic features (Fig. 2),

Table 2

Moho depth $(\mathrm{H})$ estimated by Ps picked method.

\begin{tabular}{llll}
\hline Stations & $\mathrm{N}$ & $\mathrm{H}(\mathrm{km})$ & $\mathrm{K}$ \\
\hline ARCH (line D) & 5 & 32.3 & 1.80 \\
BMES (line A) & 5 & 41.9 & 1.80 \\
GADC (line A) & 4 & 36.4 & 1.85 \\
GIMB (line A) & 9 & 44.5 & 1.75 \\
JAKH (line D) & 9 & 19.0 & 1.80 \\
MARG (line A) & 3 & 25.5 & 1.80 \\
MIRB (line A) & 3 & 45.4 & 1.74 \\
PAPH (line A) & 9 & 42.3 & 1.85
\end{tabular}




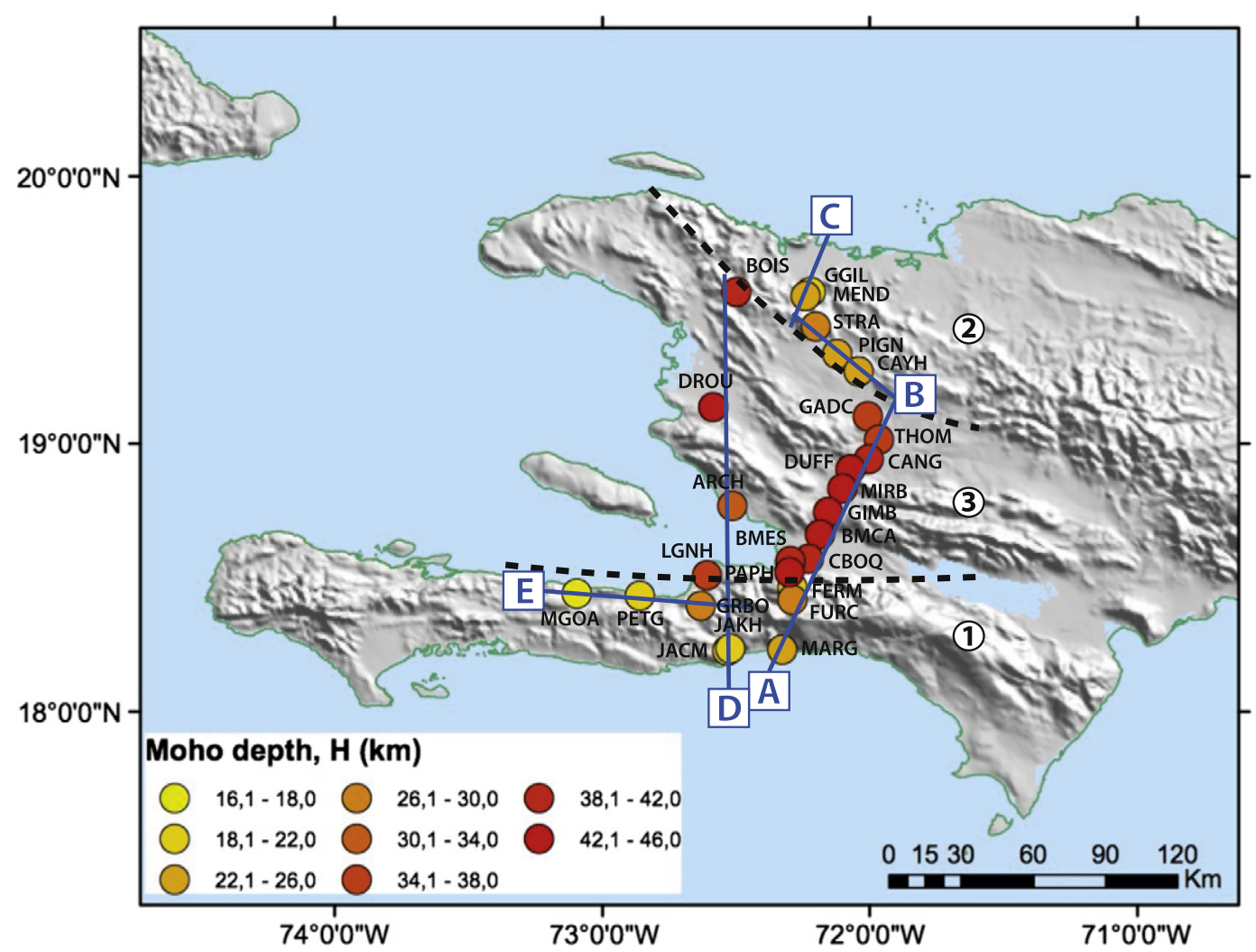

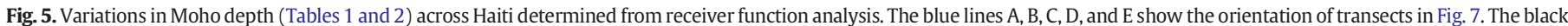
dashed lines delimit the boundary between 3 distinct domains of Moho depth values, numbered 1, 2 and 3 (see text for explanation).

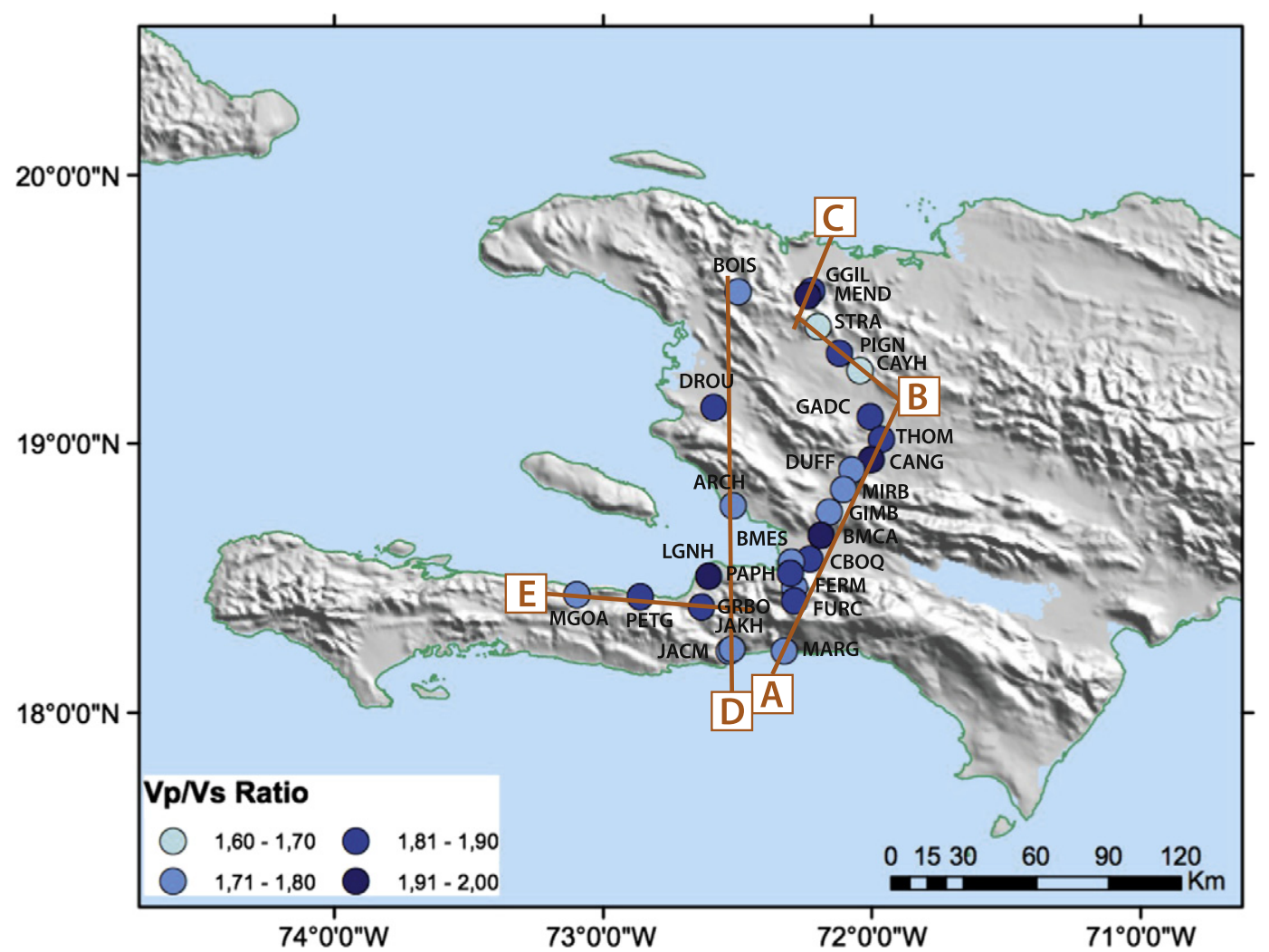

Fig. 6. Variations in Vp/Vs ratio (Tables 1 and 2) across Haiti determined from receiver function analysis. The orange lines A, B, C, D, and E show the orientation of transects in Fig. 7. 
and therefore fluid migration along active faults could feasibly locally increase the $\mathrm{Vp} / \mathrm{Vs}$ ratio. In order to interpret regional variations in crustal structure and since the interstation variability is relatively high, we calculate the mean $\mathrm{Vp} / \mathrm{Vs}$ ratio for each of the 3 domains identified in Fig. 5, excluding the four very high values. Regional averages of $\mathrm{Vp} / \mathrm{Vs}$ seem to provide more insights than single-station values, excepting for particularly high values that could show fluid migration (Rossi et al., 2006). The mean $\mathrm{Vp} / \mathrm{Vs}$ ratio is $1.75 \pm 0.10$ in the northern part of Haiti, $1.80 \pm$ 0.05 in the central part, and $1.80 \pm 0.03$ in the southern part.

\subsection{Shallow discontinuity}

In addition to $\mathrm{P}$ to $\mathrm{S}$ Moho converted phases, one station, $\mathrm{CAYH}$, exhibits another clear shallow discontinuity. The RF plot for station $\mathrm{CAYH}$ versus back-azimuth (top of Fig. 8) shows a shallow discontinuity in the first $2 \mathrm{~s}$ of the signal, prior to the Ps arrival from the Moho. Clear Moho Ps arrivals are obvious just after $2 \mathrm{~s}$, and are easily identified in the upper RFs (group a, Fig. 8), coming from the south (back-azimuths between $176^{\circ}$ and $178^{\circ}$, Fig. 8 ). The Н-к stack method for this group gives a
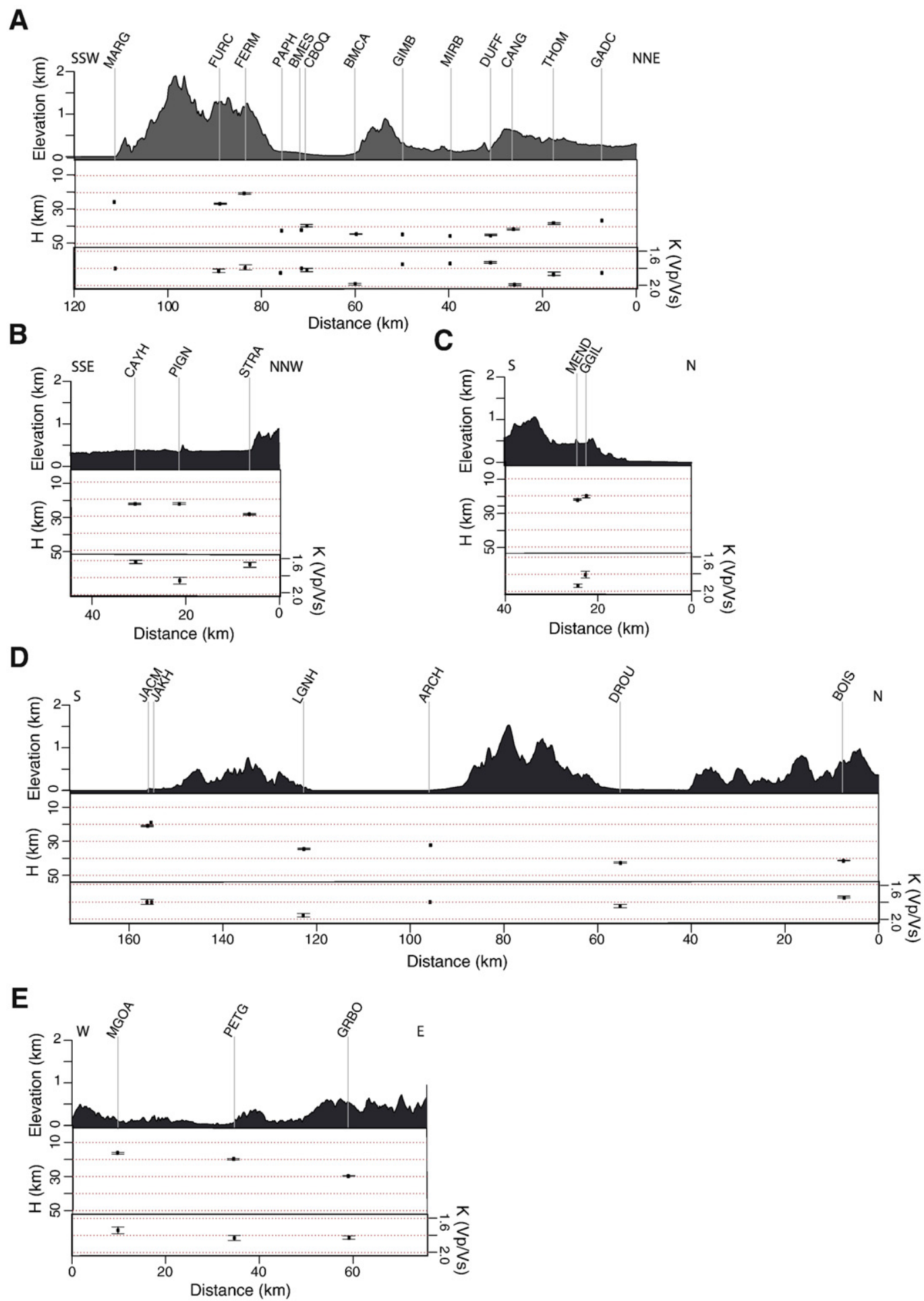

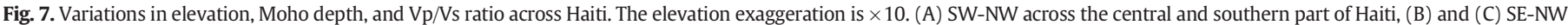

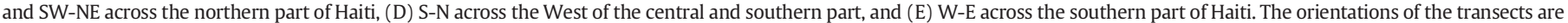
shown on Figs. 5 and 6. 
Moho depth of $22.1 \mathrm{~km}$, which is consistent with the closest station PIGN (Fig. 5 and Table 1), and a Vp/Vs ratio of 1.64. We estimate the depth of the shallow discontinuity easily visible in the RFs of the group b assuming that the upper crust has an average Vp of $5.8 \mathrm{~km} / \mathrm{s}$ and an average $\mathrm{Vp} / \mathrm{Vs}$ ratio of 1.77 . These average properties are derived from the P velocity model in Haiti of Douilly et al. (2013). This discontinuity is thus estimated at $\sim 9.7 \mathrm{~km}$ depth.

\section{Discussion}

\subsection{Identification of 3 distinct crustal domains}

The depth distribution of the Moho in Haiti shows 3 distinct regions that we relate to 3 distinct geological domains (Fig. 9).

The Southern Peninsula of Hispaniola (Fig. 9) is known to be a part of the Caribbean LIP, and to be composed of Cretaceous tholeitic material
(Calmus, 1983; Bien-Aimé Momplaisir, 1986). In this part of the island, the Moho depths from our study vary from $16.1 \mathrm{~km}$ to $29.8 \mathrm{~km}$ along a W-E profile (Fig. 7E) and from $20.5 \mathrm{~km}$ to $27.5 \mathrm{~km}$ along a N-S profile (Fig. 7A), giving an average crustal thickness of $22 \pm 5 \mathrm{~km}$. The variability of the Moho depths we image in the Southern Peninsula may reflect the large differences in the LIP thickness identified in previous studies between the oceanic crust and the areas with more or less of underplated material (Diebold et al., 1981; Mauffret and Leroy, 1997; Leroy et al., 2000; Mauffret et al., 2001). In our results the mean Vp/Vs ratio is $1.80 \pm 0.03$, consistent with previous studies (Douilly et al., 2013) and the geology of the Southern Peninsula (Calmus, 1983; Bien-Aimé Momplaisir, 1986). The northern limit of the LIP crustal domain is given by the Moho depth calculated at the station LGNH (34.6 km; Fig. 5) and could correspond to the trace of the EPGFZ (Fig. 2 ) in this area (south of LGNH), as suggested by previous studies (Saint Fleur et al., 2015).
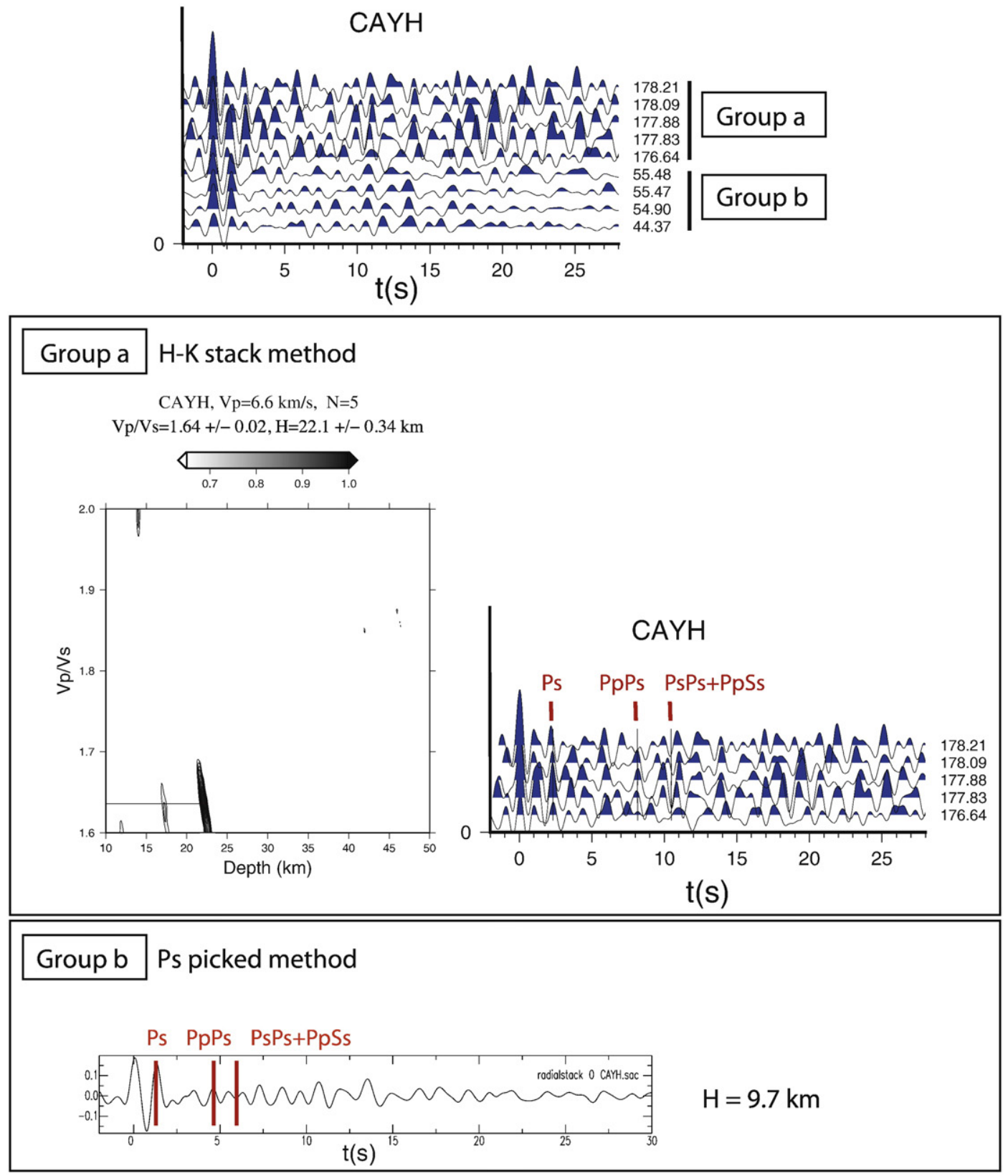

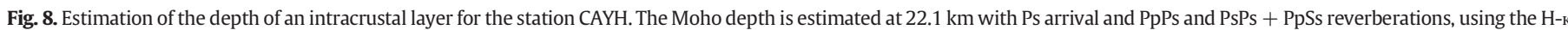

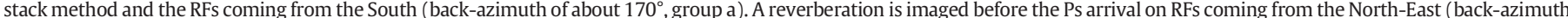
of about $55^{\circ}$, group b), and the corresponding estimated depth with Ps picked method ( $\mathrm{Vp}=5.8 \mathrm{~km} / \mathrm{s}$ and $\mathrm{K}=1.77$ ) is $9.7 \mathrm{~km}$. 


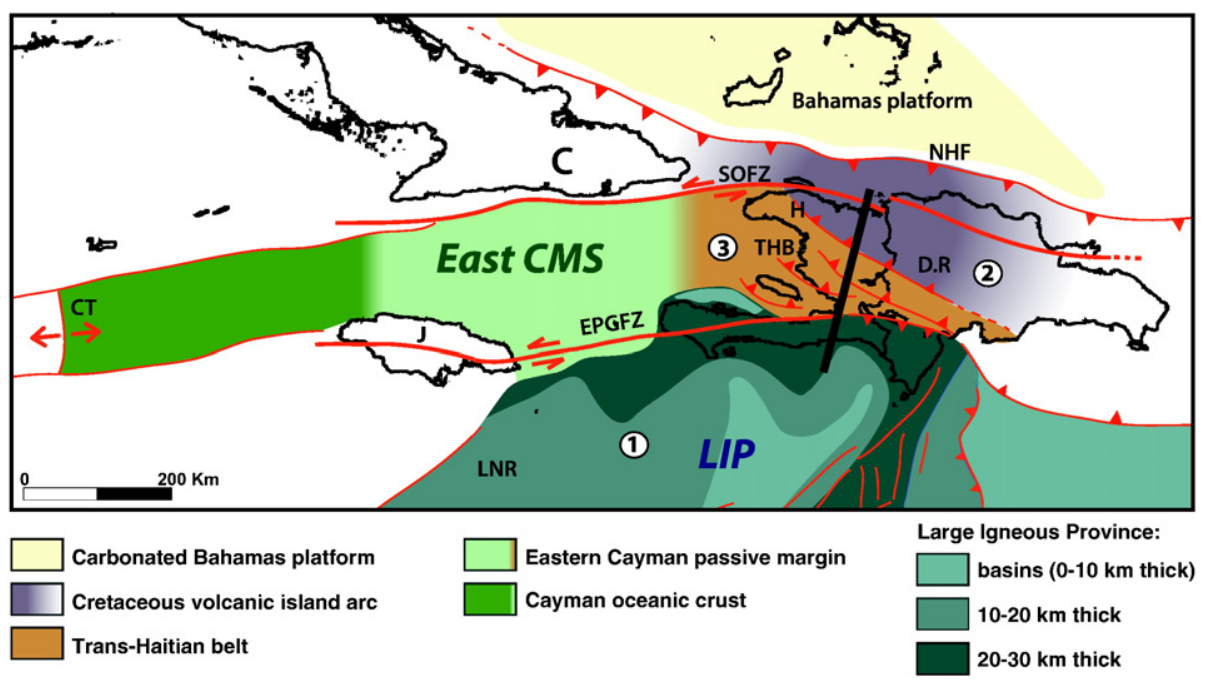

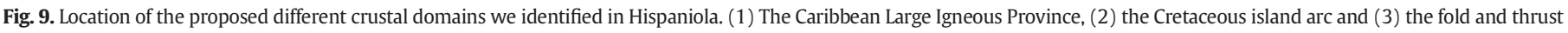

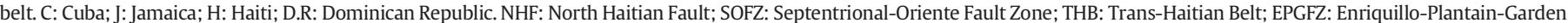

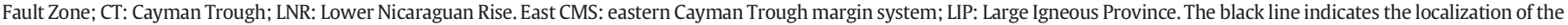
transect shown in Fig. 10. The thicknesses of the LIP at sea are from Mauffret and Leroy (1997). The boundary between the East CMS and the LIP at sea is from Corbeau et al. (2016a).

The northern part of Hispaniola (Fig. 9) is known to be a part of the Great Arc of the Caribbean (Burke, 1988), an inactive intra-oceanic island arc formed in the Cretaceous at the boundary of the Pacific domain and the proto-Caribbean oceanic crust (Pindell et al., 2006). The Moho depth values we compute are ranging between $20.1 \mathrm{~km}$ and $28.2 \mathrm{~km}$, providing an average crustal thickness of $23 \pm 3 \mathrm{~km}$ in agreement with the values found in southern Cuba (approximately $20 \mathrm{~km}$, Moreno et al., 2002; González et al., 2012) and eastern Hispaniola (about 24 km, Nuñez et al., 2015). Furthermore, our results delineate the southwestern limit of the island arc domain. The shift of the Moho depths, from $22.1 \mathrm{~km}$ (CAYH) to $36.4 \mathrm{~km}$ (GADC), occurs across the trace of a major thrust evidenced by geological studies (Figs. 5 and 9). Both this major thrust and the sharp offset of the Moho depths outline a distinct crustal domain to the west and south of this feature.

In addition to the southern and northern domains discussed above, we identify a central domain distinct from both the LIP in the South and the island arc in the North (Fig. 9), which is characterized by a thicker crust ranging from $32.3 \mathrm{~km}$ to $45.4 \mathrm{~km}$, with an average of 41 $\pm 4 \mathrm{~km}$. The relatively deep Moho is well constrained by 13 stations. In addition, the preliminary results of a recent seismic refraction study by Nuñez et al. (2015) indicate that the thickness of the crust increases from eastern Hispaniola towards the west reaching a value of $\sim 40 \mathrm{~km}$ at the boundary between Haiti and the Dominican Republic near our profile. The Cul-de-Sac sedimentary basin (Fig. 1) and the Trans-Haitian belt belong to the same thick domain, where the nature of the crust below these superficial structures has still to be determined. We further discuss the different hypothesis regarding the nature of the crust of this domain.

\section{2. $\mathrm{Vp} / \mathrm{Vs}$ ratio}

We find very high $\mathrm{Vp} / \mathrm{Vs}$ ratios, between 1.94 and 1.99 at four stations, located near major faults: LGNH near the strike-slip EPGFZ and MEND, CANG and BMCA near the main thrust faults (Figs. 2 and 6).

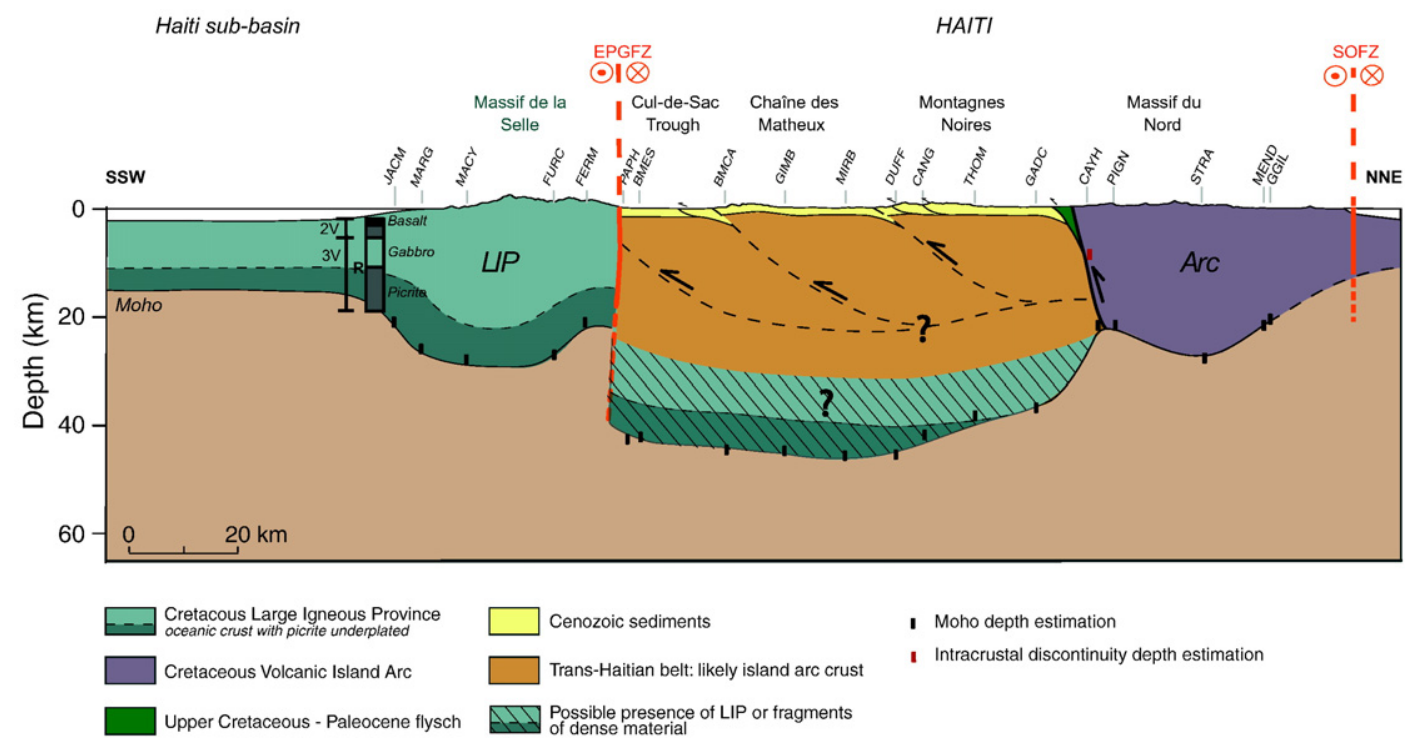

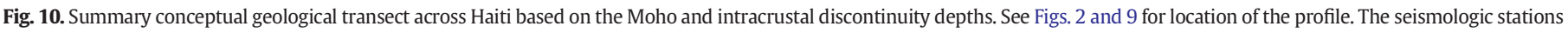

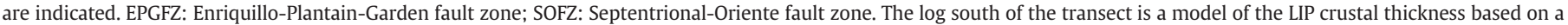

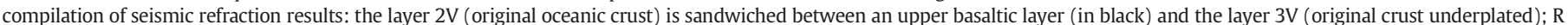
is the top of a high velocity layer (Mauffret and Leroy, 1997). 
High $\mathrm{Vp} /$ Vs ratios are often associated with partial melt, basaltic intrusions or the presence of fluids (Stuart et al., 2006; Hammond et al., 2011). We favor an explanation whereby the high Vp/Vs ratios associated with major crustal faults are related to the presence of fluids within the fault zones (Thurber et al., 2003; Zhao et al., 1996). Nevertheless, all the stations located near major faults do not present high $\mathrm{Vp} / \mathrm{Vs}$ values (e.g. CAYH, fig. 2).

The mean $\mathrm{Vp} / \mathrm{Vs}$ ratio $(1.80 \pm 0.03$ ) found in the southern domain is in agreement with its late Cretaceous oceanic plateau origin (Christensen, 1996; Douilly et al., 2013). In the northern domain composed of a late Cretaceous-Eocene, intra-oceanic volcanic arc and forearc-accretionary prism, the $\mathrm{Vp} / \mathrm{Vs}$ ratio of $1.75 \pm 0.10$ is close to that expected for the average continental crust, 1.768 (Christensen, 1996). The central part of Haiti is characterized by $\mathrm{Vp} / \mathrm{Vs}$ ratio of 1.80 \pm 0.05 , indicating that mafic rocks may be part of the crustal lithology of this domain as in the southern domain.

\subsection{Implications for the tectonic history of Hispaniola}

We identify three distinct tectonic domains with different crustal thickness and bulk composition. Based on our computed Moho depths and $\mathrm{Vp} / \mathrm{Vs}$ ratios, and with additional constraints from the major thrusts identified at the surface and the geodynamic reconstructions (Leroy et al., 2000; Pubellier et al., 2000; Calais et al., 2016), we propose a geological model along a N-S profile across Haiti (Fig. 10). This transect shows the LIP in the South, the Cretaceous volcanic arc in the North, and a central thicker domain.

The central domain is characterized by relatively thick crust of $\sim 41 \mathrm{~km}$, between two domains with significantly thinner crusts of 20-30 km. Surprisingly, the thick crust of the central domain is not associated with major relief $(\sim 1 \mathrm{~km})$. Based on field studies and geodynamic reconstructions proposed for this area (e.g. Stéphan et al., 1990; Meschede and Frisch, 1998; Mann et al., 1991; Calais et al., 2016), the nature of the crust of the central domain is likely to be island arc and fore-arc type, considered as either back-arc (Mann and Lawrence, 1991) or a Cretaceous-Eocene remnant arc (Heubeck et al., 1991). Other stratigraphic and tectonic studies (e.g. Pubellier et al., 2000) suggest that the fold-and-thrust belt of this crustal domain may be rooted on the continuation of the rifted crust of the eastern Cayman continental passive margin (Fig. 9). However, Vp/Vs ratio of 1.80 , typical for mafic rocks (average of values for this domain; Tables 1 \& 2), may indicate that the central crustal domain could not be composed only of island arc crust, and may imply the presence of dense material. This dense material could be either related to Pliocene-Quaternary mafic center of volcanism coming from an ancient continental mantle lithosphere fragment (Kamenov et al., 2011) or associated to LIP material fragment coming from the south and both trapped early in central Haiti. Geochemical studies of the LIP south of Hispaniola from submersible dive samples (Revillon et al., 2000; Mauffret et al., 2001) show indeed that the lower part of the LIP is made of ultra-mafic rocks and geophysical studies (Mauffret and Leroy, 1997; 1999) evidence a high velocity layer composed of dense material (velocity 7.5 to $7.9 \mathrm{~km} / \mathrm{s}$; density of 3 to 3.1; Herzberg et al., 1983). The mafic Quaternary rocks are also MgO-rich (Kamenov et al., 2011) and give high $\mathrm{Vp} / \mathrm{Vs}$ ratio.

On the transect in Fig. 10 we also draw the intracrustal discontinuity determined from our receiver functions at the station CAYH. The estimated depth of this intracrustal discontinuity $(\sim 10 \mathrm{~km})$ may provide information on the possible depth for the Late-Cretaceous to Pleistocene flysch of the Peralta belt (Witschard and Dolan, 1990; Dolan et al., 1991), which outcrops at the front of the Cretaceous volcanic arc (Fig. 10). At the surface, three major thrusts are geologically mapped (the Montagnes Noires, the Chaîne des Matheux and the Gonâve Island; Figs. 1 and 2; Mann et al., 1995; Pubellier et al., 2000; Hernaiz Huerta et al., 2007). In our transect, we propose to extend these thrusts to greater depth along three large crustal slices (Fig. 10). The three major thrusts of the TransHaitian belt show small cumulative throws at outcrop and little evidence of strong compressional tectonics (Mann et al., 1995; Pubellier et al., 2000; Corbeau et al., 2016b). SW-vergent fold-and-thrust belt related to the Hispaniola restraining bend and back arc basin collapse (Heubeck et al., 1991) could have contributed to the overall thickening.

\section{Conclusions}

A receiver function study of 23 stations is used to determine the crustal structure across Haiti, in order to place better constraints on the history and geometry of late Cretaceous to recent terrane accretion. In the northern part of Haiti, consisting of the Cretaceous volcanic island arc and forearc of the Greater Antilles, the Moho discontinuity is imaged at a depth of $\sim 23 \mathrm{~km}$ with $\mathrm{Vp} / \mathrm{Vs}$ ratio of 1.75 . In the southern part of Haiti, made of the folded and thrusted Cretaceous oceanic Large Igneous Province (LIP), the Moho depth is imaged at $\sim 22 \mathrm{~km}$, and Vp/Vs ratio is 1.80. In the central part of Haiti, encompassing the Haitian fold-andthrust belt, the Moho discontinuity is deeper with a mean depth of $\sim 41 \mathrm{~km}$. We propose that this unexpected thick central domain with $\mathrm{Vp} / \mathrm{Vs}$ ratio of 1.80 corresponds to a distinct crustal domain. This domain is likely to consist of island-arc type crust related to the Great Arc of the Caribbean, or the proximal part of the Cayman Trough eastern passive margin, associated with mafic material coming from fragments of lithospheric mantle from the north or mafic LIP material from the south.

\section{Acknowledgements}

The seismological equipment was loaned from the SEIS-UK equipment pool and from the ISTeP facilities. The facilities of SEIS-UK are supported by the Natural Environment Research Council (NERC) under Agreement R8/H10/64. DK time on the research is funded by NERC grant NE/L013932/1. This work could not have been done without Gérard Laborde and DIGICEL, and without our collaboration with the Bureau des Mines et de l'Energie and the Université d'Etat d'Haiti in Haiti. The paper benefits from fruitful discussions with Nicolas Bellahsen and Claudio Rosenberg. We thank the Editor, the reviewer David Schlaphorst and an anonymous reviewer for their constructive comments that helped improved the manuscript.

\section{References}

Abers, G.A., Hu, X., Sykes, L.R., 1995. Source scaling of earthquakes in the Shumagin region, Alaska: time-domain inversions of regional waveforms. Geophys. J. Int. 123 (1), 41-58.

Ammon, C.J., 1991. The isolation of receiver effects from teleseismic P waveforms. Bull. Seismol. Soc. Am. 81 (6), 2504-2510.

Bien-Aimé Momplaisir, R., 1986. Contribution à l'étude géologique de la partie orientale du Massif de la Hotte (Presqu'île du Sud d'Haïti): Synthèse structurale des marges de la presqu'île à partir de données sismiques, thèse de doctorat. ( $\mathrm{Ph}$. D. thesis, 210 pp.). Univ. Pierre-et-Marie-Curie (Paris VI), Paris.

Boisson, D., 1987. Etude geologique du massif du nord d'Haiti (Hispaniola-grandes Antilles), thèse de doctorat. (Ph. D. thesis). Univ. Pierre et Marie Curie (Paris VI), Paris.

Bowin, C.O., 1976. Caribbean gravity field and plate tectonics. Geol. Soc. Am. Spec. Pap. 169.

Burke, K., 1988. Tectonic evolution of the Caribbean. Annu. Rev. Earth Planet. Sci. 16 201-230.

Calais, E., Mercier de Lepinay, B., 1991. From transtension to transpression along the northern Caribbean plate boundary off Cuba: implications for the recent motion of the Caribbean plate. Tectonophysics 186 (3), 329-350.

Calais, E., Symithe, S., Mercier de Lépinay, B., Prépetit, C., 2016. Plate boundary segmentation in the northeastern Caribbean from geodetic measurements and Neogene geological observations. Compt. Rendus Geosci. 348 (1), 42-51.

Calmus, T. 1983. Contribution à l'étude géologique du massif de Macaya(sud-ouest d'Haïti, Grandes Antilles): sa place dans l'évolution de l'orogène Nord-Caraïbe, thèse de doctorat. Univ. Paris VI, Paris.

Chevrot, S., van der Hilst, R.D., 2000. The Poisson ratio of the Australian crust: geological and geophysical implications. Earth Planet. Sci. Lett. 183 (1), 121-132. 
Christensen, N.I., 1996. Poisson's ratio and crustal seismology. J. Geophys. Res. Solid Earth 101 (B2), 3139-3156 (1978-2012).

Corbeau, J., Rolandone, F., Leroy, S., Mercier de Lépinay, B., Meyer, B., Ellouz-Zimmermann, N., Momplaisir, R., 2016a. The Northern Caribbean plate boundary in the Jamaica Passage: structure and seismic stratigraphy. Tectonophysics 675, 209-226.

Corbeau, J., Rolandone, F., Leroy, S., Meyer, B., Mercier de Lépinay, B., Ellouz-Zimmermann, N., Momplaisir, R., 2016b. How transpressive is the Northern Caribbean plate boundary? Tectonics http://dx.doi.org/10.1002/2015TC003996.

Cruz-Orosa, I., Sàbat, F., Ramos, E., Rivero, L., Vázquez-Taset, Y.M., 2012. Structural evolution of the La Trocha fault zone: oblique collision and strike-slip basins in the Cuban Orogen. Tectonics 31 (5).

Diebold, J., Stoffa, P., Buhl, P., Truchan, M., 1981. Venezuela Basin crustal structure. J. Geophys. Res. Solid Earth 86 (B9), 7901-7923 (1978-2012)

Dolan, J., Mann, P., de Zoeten, R., Heubeck, C., Shiroma, J., Monechi, S., 1991. Sedimentologic, stratigraphic, and tectonic synthesis of Eocene-Miocene sedimentary basins, Hispaniola and Puerto Rico. Geol. Soc. Am. Spec. Pap. 262, 217-264.

Douilly, R., Haase, J.S., Ellsworth, W.L., Bouin, M.-P., Calais, E., Symithe, S.J., Armbruster J.G., Mercier de Lépinay, B., Deschamps, A., Mildor, S.-L., collab, 2013. Crustal structure and fault geometry of the 2010 Haiti earthquake from temporary seismometer deployments. Bull. Seismol. Soc. Am. 103 (4), 2305-2325.

Duncan, R., Hargraves, R., 1984. Plate tectonic evolution of the Caribbean region in the mantle reference frame. Geological Society of America Memoirs 162, 81-94.

Escuder Viruete, J., Contreras, F., Stein, G., Urien, P., Joubert, M., Ullrich, T.D., Mortensen, J. Perez Estaun, A., 2006. Transpression and strike-slip partitioning in the Caribbean island arc: fabric development, kinematics and $\mathrm{Ar}-\mathrm{Ar}$ ages of syntectonic emplacement of the Loma de Cabrera batholith, Dominican Republic. J. Struct. Geol. 28, 1496-1519.

González, O., Moreno, B., Romanelli, F., Panza, G.F., 2012. Lithospheric structure below seismic stations in Cuba from the joint inversion of Rayleigh surface waves dispersion and receiver functions. Geophys. J. Int. 189, 1047-1059.

Granja-Bruña, J., Carbó-Gorosabel, A., Estrada, P.L., Muñoz-Martín, A., ten Brink, U., Ballesteros, M.G., Druet, M., Pazos, A., 2014. Morphostructure at the junction between the Beata ridge and the Greater Antilles island arc (offshore Hispaniola southern slope). Tectonophysics 618, 138-163.

Gurrola, H., Baker, G.E., Minster, J.B., 1995. Simultaneous time-domain deconvolution with application to the computation of receiver functions. Geophys. J. Int. 120 (3), 537-543.

Hammond, J., Kendall, J.-M., Stuart, G., Keir, D., Ebinger, C., Ayele, A., Belachew, M., 2011 The nature of the crust beneath the Afar triple junction: evidence from receiver functions. Geochem. Geophys. Geosyst. 12 (12).

Hammond, J., Kendall, J.-M., Stuart, G., Ebinger, C., Bastow, I., Keir, D., Ayele, A., Belachew, M., Goitom, B., Ogubazghi, G., collab, 2013. Mantle upwelling and initiation of rift segmentation beneath the Afar Depression. Geology 41 (6), 635-638.

Hastie, A.R., Mitchell, S.F., Treloar, P.J., Kerr, A.C., Neill, I., Barfod, D.N., 2013. Geochemica components in a Cretaceous island arc: the $\mathrm{Th} / \mathrm{La}-\left(\mathrm{Ce} / \mathrm{Ce}^{*}\right) \mathrm{Nd}$ diagram and implications for subduction initiation in the inter-American region. Lithos 162, 57-69.

Helffrich, G., 2006. Extended-time multitaper frequency domain cross-correlation receiver-function estimation. Bull. Seismol. Soc. Am. 96 (1), 344-347.

Helffrich, G., Faria, B., Fonseca, J.F., Lodge, A., Kaneshima, S., 2010. Transition zone structure under a stationary hot spot: Cape Verde. Earth Planet. Sci. Lett. 289 (1), 156-161.

Hernaiz Huerta, P.P., Diaz de Neira, J.A., Garcia Senz, J., Deschamps, I., Genna, A., Nicole, N. Lopera, E., Escuder Virruete, J., Ardevol Oro, Ll., Perez Estaun, A., 2007. La estructura del suroeste de la Republica Dominicana: un ejemplo de deformacion en regimen transpresivo. Bol. Geol. Min. 118 (2), 337-358.

Herzberg, C., Fyfe, W., Carr, M., 1983. Density constraints on the formation of the continental Moho and crust. Contrib. Mineral. Petrol. 84 (1), 1-5.

Heubeck, C., Mann, P., Dolan, J., Monechi, S., 1991. Diachronous uplift and recycling of sedimentary basins during Cenozoic tectonic transpression, northeastern Caribbean plate margin. Sediment. Geol. 70 (1), 1-32.

Iturralde-Vinent, M.A., 2006. Meso-Cenozoic Caribbean paleogeography: implications for the historical biogeography of the region. Int. Geol. Rev. 48 (9), 791-827.

Kamenov, G.D., et al., 2011. Ancient lithospheric source for Quaternary lavas in Hispaniola. Nat. Geosci. 4, 554-557.

Kennet, B., 1991. IASPEI 1991 seismological tables. Terra Nova 3 (2), 122.

Langston, C.A. 1979. Structure under Mount Rainier, Washington, inferred from teleseismic body waves. J. Geophys. Res. Solid Earth 84 (B9), 4749-4762 (19782012).

Leroy, S., Mercier de Lépinay, B., Mauffret, A., Pubellier, M., 1996. Structural and tectonic evolution of the eastern Cayman trough (Caribbean Sea) from seismic reflection data. AAPG Bull. 80 (2), 222-247.

Leroy, S., Mauffret, A., Patriat, P., Mercier de Lépinay, B., 2000. An alternative interpretation of the Cayman trough evolution from a reidentification of magnetic anomalies. Geophys. J. Int. 141 (3), 539-557.

Leroy, S., Ellouz-Zimmermann, N., Corbeau, J., Rolandone, F., Lépinay, B.M., Meyer, B., .. Burov, E., 2015. Segmentation and kinematics of the North America-Caribbean plate boundary offshore Hispaniola. Terra Nova 27 (6), 467-478.

Ligorría, J.P., Ammon, C.J., 1999. Iterative deconvolution and receiver-function estimation. Bull. Seismol. Soc. Am. 89 (5), 1395-1400.

Lodge, A., Nippress, S., Rietbrock, A., García-Yeguas, A., Ibáñez, J., 2012. Evidence for magmatic underplating and partial melt beneath the Canary Islands derived using teleseismic receiver functions. Phys. Earth Planet. Inter. 212, 44-54.

Mann, P., Lawrence, S., 1991. Petroleum potential of southern Hispaniola. J. Pet. Geol. 14 (2), 291-308

Mann, P., Draper, G., Lewis, J.F., 1991. An overview of the geologic and tectonic development of Hispaniola. Geol. Soc. Am. Spec. Pap. 262, 1-28.
Mann, P., Taylor, F., Edwards, R.L., Ku, T.-L., 1995. Actively evolving microplate formation by oblique collision and sideways motion along strike-slip faults: an example from the northeastern Caribbean plate margin. Tectonophysics 246 (1), 1-69.

Martinez-Arevalo, C., de Lis Mancilla, F., Helffrich, G., Garcia, A., 2013. Seismic evidence of a regional sublithospheric low velocity layer beneath the Canary Islands. Tectonophysics 608, 586-599.

Mauffret, A., Leroy, S., 1997. Seismic stratigraphy and structure of the Caribbean igneous province. Tectonophysics 283 (1), 61-104.

Mauffret, A., Leroy, S., 1999. Neogene intraplate deformation of the Caribbean plate at theBeata Ridge. Sediment. Basins World 4, 627-669.

Mauffret, A., Leroy, S., d'Acremont, É., Maillard, A., Mercier de Lépinay, B., Dos Reis, A.T., Miller, N., Nercessian, A., Pérez-Vega, R., Perez, D., 2001. Une coupe de la province volcanique Caraïbe: premiers résultats de la campagne sismique Casis 2. Comptes Rendus de l'Académie des Sciences-Series IIA-Earth and Planetary Science 333 (10), 659-667.

McNamara, D., Meremonte, M., Maharrey, J., Mildore, S.-L., Altidore, J., Anglade, D., Hough, S., Given, D., Benz, H., Gee, L., collab, 2012. Frequency-dependent seismic attenuation within the Hispaniola Island region of the Caribbean Sea. Bull. Seismol. Soc. Am. 102 (2), 773-782.

Meschede, M., Frisch, W., 1998. A plate-tectonic model for the Mesozoic and Early Cenozoic history of the Caribbean plate. Tectonophysics 296 (3), 269-291.

Moreno, B., Grandison, M., Atakan, K., 2002. Crustal velocity model along the southern Cuban margin: implications for the tectonic regime at an active plate boundary. Geophys. J. Int. 151 (2), 632-645.

Nuñez, D., Cordoba, D., Nuñez-Cornu, F.J., Cotilla, M.O., 2015. Lithosphere structure from Cordillera Central to Cordillera Oriental (Dominican Republic). EGU General Assembly Conference Abstracts vol. 17, p. 14467.

Owens, T., Taylor, S., Zandt, G., 1983. Isolation and Enhancement of the Response of Local Seismic Structure from Teleseismic P-waveforms. cahier de recherche. Lawrence Livermore National Lab, CA (USA).

Park, J., Levin, V., 2000. Receiver functions from multiple-taper spectral correlation estimates. Bull. Seismol. Soc. Am. 90 (6), 1507-1520.

Pindell, J., Kennan, L., Stanek, K.P., Maresch, W., Draper, G., 2006. Foundations of Gulf of Mexico and Caribbean evolution: eight controversies resolved. Geol. Acta 4 (1-2), 303.

Pindell, J., Maresch, W.V., Martens, U., Stanek, K., 2012. The Greater Antillean Arc: Early Cretaceous origin and proposed relationship to central American subduction mélanges: implications for models of Caribbean evolution. Int. Geol. Rev. 54 (2), $131-143$.

Pubellier, M., Mauffret, A., Leroy, S., Vila, J.M., Amilcar, H., 2000. Plate boundary readjustment in oblique convergence: example of the Neogene of Hispaniola, Greater Antilles. Tectonics 19 (4), 630-648.

Revillon, S., Hallot, E., Arndt, N., Chauvel, C. Duncan, R., 2000. A complex history for the Caribbean Plateau: petrology, geochemistry, and geochronology of the Beata Ridge, South Hispaniola. J. Geol. 108 (6), 641-661.

Rossi, G., Abers, G.A., Rondenay, S., Christensen, D.H., 2006. Unusual mantle Poisson's ratio, subduction, and crustal structure in central Alaska. J. Geophys. Res. Solid Earth 111 (B9).

Saint Fleur, N., Feuillet, N., Grandin, R., Jacques, E., Weil-Accardo, J., Klinger, Y., 2015. Seismotectonics of southern Haiti: a new faulting model for the 12 January 2010 M7 earthquake. Geophys. Res. Lett.

Stéphan, J.-F., Mercier de Lépinay, B., Calais, E., Tardy, M., 1990. Paleogeodynamic maps of the Caribbean: 14 steps from Lias to present. Bull. Soc. Geol. Fr. 0-6.

Stuart, G., Bastow, I., Ebinger, C., 2006. Crustal structure of the northern Main Ethiopian Rift from receiver function studies. Geol. Soc. Lond., Spec. Publ. 259 (1), 253-267.

Symithe, S., Calais, E., 2016. Present-day shortening in Southern Haiti from GPS measurements and implications for seismic hazard. Tectonophysics 679, 117-124.

Symithe, S., Calais, E., Chabalier, J.B., Robertson, R., Higgins, M., 2015. Current block motions and strain accumulation on active faults in the Caribbean. J. Geophys. Res. Solid Earth 120 (5), 3748-3774.

Thompson, D., Bastow, I., Helffrich, G., Kendall, J., Wookey, J., Snyder, D., Eaton, D., 2010. Precambrian crustal evolution: seismic constraints from the Canadian Shield. Earth Planet. Sci. Lett. 297:655-666. http://dx.doi.org/10.1016/j.epsl.2010.07.021.

Thurber, C., Roecker, S., Roberts, K., Gold, M., Powell, L., Rittger, K., 2003. Earthquake locations and three-dimensional fault zone structure along the creeping section of the San Andreas fault near Parkfield, CA: Preparing for SAFOD. Geophys. Res. Lett. 30 (3).

Van Der Lelij, R., 2013. Reconstructing North-Western Gondwana with Implications for the Evolution of the Iapetus and Rheic Oceans: A Geochronological, Thermochronological and Geochemical Study. (thèse de doctorat). University of Geneva.

Watanabe, T., 1993. Effects of water and melt on seismic velocities and their application to characterization of seismic reflectors. Geophys. Res. Lett. 20 (24), 2933-2936.

Witschard, M., Dolan, J.F., 1990. Contrasting structural styles in siliciclastic and carbonate rocks of an offscraped sequence: the Peralta accretionary prism, Hispaniola. Geol. Soc. Am. Bull. 102 (6), 792-806.

Zandt, G., Ammon, C.J., 1995. Continental crust composition constrained by measurements of crustal Poisson's ratio. Nature 374 (6518), 152-154.

Zhao, D., Kanamori, H., Negishi, H., Wiens, D., 1996. Tomography of the source area of the 1995 Kobe earthquake: evidence for fluids at the hypocenter? Science 274 (5294), 1891-1894.

Zhu, L., Kanamori, H., 2000. Moho depth variation in southern California from teleseismic receiver functions. J. Geophys. Res. B 105 (B2), 2969-2980. 